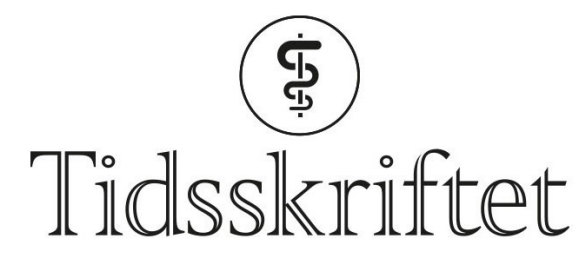

DEN NORSKE LEGEFORENING

\title{
Nytt og nyttig for veiledere
}

ANMELDELSER

IVAR J. AARAAS

Professor,Institutt for samfunnsmedisin

Universitetet i Troms $\varnothing$ - Norges arktiske universitet

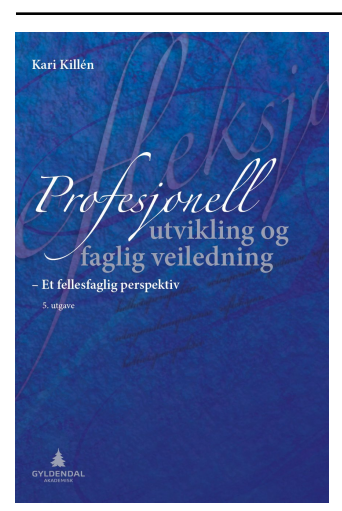

Kari Killén

Profesjonell utvikling og faglig veiledning

Et fellesfaglig perspektiv. 5. utg. 283 s. Oslo: Gyldendal Akademisk, 2017. Pris NOK 429

ISBN 978-82-05-50073-0

Denne boken er en «klassiker» blant norske bøker om helse- og sosialfaglig veiledning. Første utgave kom i 1979. Forfatterens begrunnelse for enda en ny revidert utgave, den femte i rekken, er en stadig økning av relevant forskningsbasert kunnskap om omsorgssvikt, traumer, stress og sykdomsskapende utviklingstrekk i vårt moderne samfunn. Avstanden mellom praksis og den kunnskap som er tilgjengelig, er lang og $\emptyset$ kende. Alle utdanninger som har helsefremmende, relasjonsbasert arbeid som et primært siktemål, trenger stadig fornyelse og oppdatert kunnskap for å møte personer og familier som søker hjelp, på en faglig etisk forsvarlig måte. For å lykkes med dette er det en økende erkjennelse av behovet for veiledet praksis i utdanningen av alt helse- og sosialpersonell, inkludert leger og pedagoger.

Gjennom syv kapitler gjennomgår forfatteren veiledningens ulike former, målsettinger, funksjoner, hjelpemidler, prosesser og metoder. Hovedvekten er lagt på individuell veiledning. Gruppeveiledning er fyldig omtalt i et særskilt kapittel. Forfatteren gir mange konkrete eksempler på hvordan et tillitsfullt og ansvarlig forhold, der veileder og veiledet begge er aktive, kan utvikles positivt. Boken inneholder også mange lærerike eksempler på hvordan man kan motvirke motstand, motløshet og negativitet i veiledningsforhold.

I pågående revisjoner av norske medisinske grunnutdanninger er veiledning i relasjons- og 
kommunikasjonskompetanse anerkjent som et viktig element. I Tromsø er denne veiledningen obligatorisk, gruppebasert og foregår gjennom hele studieforløpet. Kolleger som nå pålegges veiledningsoppgaver for medisinstudenter, vil ha stor nytte av denne boken.

Om man ikke kan prioritere å lese hele boken, vil jeg anbefale to sentrale kapitler: Faser og utfordringer i profesjonell utvikling og Gruppeveiledning. Disse har referanser til utfyllende lesing i øvrige kapitler. Mange praktiske eksempler på gjennomføring av veiledningssamtaler er godt beskrevet. Forfatterens refleksjoner, der hun forankrer eksemplariske praksissituasjoner til teoretisk kunnskap, bidrar vesentlig til bokens kvalitet og nytteverdi.

Publisert: 22. januar 2018. Tidsskr Nor Legeforen. DOI: 10.4045/tidsskr.17.0925

(C) Tidsskrift for Den norske legeforening 2020. Lastet ned fra tidsskriftet.no 